\title{
The Detection and Variation of Strawberry mottle virus
}

\author{
J. R. Thompson and W. Jelkmann, BBA, Institut für Pflanzenschutz im Obstbau, Schwabenheimer Straße 101, D- \\ 69221, Dossenheim, Germany
}

\begin{abstract}
Thompson, J. R., and Jelkmann, W. 2003. The detection and variation of Strawberry mottle virus. Plant Dis. 87:385-390.

Strawberry mottle virus $(\mathrm{SMoV})$ is probably the most important virus to infect strawberry (Fragaria spp.). All species of strawberry are susceptible to $\mathrm{SMoV}$, resulting in severe losses both in fruit and runner yield. However, due to the absence of definitive symptoms in commercial varieties, the only effective means of detecting $\mathrm{SMoV}$ is by transmission to susceptible indicator plants. In this study, we describe a reverse transcription-polymerase chain reaction (RT-PCR) method for the detection of SMoV in Fragaria spp. with the use of primers specific for the noncoding regions (NCR) of both RNA1 and RNA2 of the virus. Using this method, all of 16 isolates from various geographical origins were positive for SMoV. Partial sequences of a 327nt long coding region were obtained for the putative large coat protein of all isolates by RT-PCR using degenerate primers. Nucleotide identities between isolates ranged from 72.8 to $99.7 \%$. A 546-nt sequence of the putative polymerase gene of nine isolates was obtained by RT-PCR and compared. Nucleotide identities ranged from 73.4 to $100 \%$. There was a clear tendency for isolates to group according to their geographical origin. Sequence data obtained of the NCR show four completely conserved regions of 20 or more bases.
\end{abstract}

Additional keywords: CLUSTAL X, conserved amino acid motifs, extraction method, phylogenetic analysis

Strawberry mottle virus $(\mathrm{SMoV})$ is the most economically important virus to infect strawberries (Fragaria spp.), both in terms of its geographical distribution and in the potential loss in yield it can cause. Reductions in fruit yield and runner production in single infections can be as high as $30 \%$. In mixed infections with one or more of the other main strawberry infecting aphid-borne viruses, Strawberry mild yellow edge virus (SMYEV), Strawberry crinkle virus (SCV), and Strawberry vein banding virus (SVBV), losses can be up to $80 \%(3,12)$. The classification of SMoV, as a virus species, was until the 1950s often vague due to the similarities in the symptoms it induced in Fragaria spp. with those of SCV. The names "Mild crinkle" (20) and "virus I" (19) were eventually superseded by "mottle" (24). Nevertheless, a clear distinction between SMoV and SCV was made when the virus-vector relationships were clarified: $\mathrm{SMoV}$ is transmitted in a semipersistent manner, and SCV in a persistent manner. Attempts to further characterize SMoV had limited success because of difficulties in purifying the virus from infected plants, including her-

Corresponding author: J. R. Thompson

E-mail: Jeremy.Thompson@urz.uni-heidelberg.de

Accepted for publication 4 November 2002.

Publication no. D-2003-0128-01R

(C) 2003 The American Phytopathological Society baceous hosts. Isolation of two doublestranded RNAs and isometric particles of approximately $30 \mathrm{~nm}$ in diameter in SMoV-infected plants was confirmed in various independent reports $(6,8,9,28)$. Recently, the complete nucleotide sequence of SMoV was elucidated (26). In genomic organization, it is closest to nepoviruses (11); however, because of its aphid transmissibility and its close similarity to Satsuma dwarf virus (SDV) and related viruses, it has been tentatively ascribed to a separate virus group of SDVlike lineage of picorna-like viruses (5).

All species of Fragaria are susceptible to $\mathrm{SMoV}$, although identification of infection, particularly in commercial varieties, is difficult due to the absence of any defining leaf symptoms. Therefore, grafting or aphid transmission to indicator hosts is necessary in order to detect $\mathrm{SMoV}$ in commercial sources. Aphid transmission by Chaetosiphon fragaefolii is the favored method, with an acquisition access period of 4 to $6 \mathrm{~h}$, and 2 to $3 \mathrm{~h}$ transmission access. In a mixed infection, this eliminates any persistently transmitted viruses (e.g., SCV and SMYEV). Semipersistently transmitted viruses (e.g., SVBV) can be distinguished easily by symptoms (12). SMoV symptoms appear 1 to 3 weeks postinoculation, depending on the severity of the virus strain.

The purpose of this work on SMoV was firstly, to improve its detection, and secondly, to obtain information on the genetic variation among isolates of this virus species.

\section{MATERIALS AND METHODS}

Plant material. All isolates, except Dutch isolates, were maintained in Fragaria spp. in a temperature and humidity controlled greenhouse at $20^{\circ} \mathrm{C}, 70 \%$ relative humidity, and a 16-h day length with supplemented artificial illumination when necessary. The Dutch isolates were sent to us as liquid nitrogen-frozen $F$. vesca leaf material stored on dry ice. Their long-term storage was at $-80^{\circ} \mathrm{C}$. The country of origin and severity of symptoms of each isolate tested are given in Table 1.

Total nucleic acid extraction. For reverse transcription-polymerase chain reaction (RT-PCR) detection and RT-PCR of the putative large coat protein (CPL) and putative RNA-dependent RNA polymerase (RdRp) regions, the same extraction method was employed. This incorporated an extra initial step in the silica capture protocol (21), whereby $0.1 \mathrm{~g}$ of fresh or frozen leaf material was ground in $1.0 \mathrm{ml}$ SEB-buffer $(0.14 \mathrm{M} \mathrm{NaCl}, 2 \mathrm{mM} \mathrm{KCl}, 2$ $\mathrm{mM} \mathrm{KH} \mathrm{KH}_{4}, 8 \mathrm{mM} \mathrm{Na} 2 \mathrm{HPO}_{4} \cdot 2 \mathrm{H}_{2} \mathrm{O}[\mathrm{pH}$ 7.4], $0.05 \%$ vol/vol Tween $20,2 \% \mathrm{wt} / \mathrm{vol}$ polyvinylpyrrolidone 40 [PVP 40], $0.2 \%$ $\mathrm{wt} / \mathrm{vol}$ ovalbumin, $0.5 \% \mathrm{wt} / \mathrm{vol}$ bovine serum albumin, $0.05 \% \mathrm{wt} / \mathrm{vol}$ sodium azide) (27); $100 \mu \mathrm{l}$ of the homogenate was then added to $400 \mu \mathrm{l}$ of the silica capture grinding buffer (4.0 M guanidine thiocyanate, $0.2 \mathrm{M}$ sodium acetate [pH 5.2], 25 $\mathrm{mM}$ EDTA, 1.0 M potassium acetate, and $2.5 \% \mathrm{wt} / \mathrm{vol}$ PVP 40). Fresh material was ground in a Bioreba (Reinach, Switzerland) bag with a hand-held bearing homogenator, and frozen tissue in a mortar and pestle. All $500 \mu \mathrm{l}$ of the homogenatebuffer mix was then transferred to a $1.5 \mathrm{ml}$ Eppendorf tube to which was added $100 \mu \mathrm{l}$ of $10 \%$ N-lauryl sarkosyl and $5 \mu \mathrm{l}$ of 2mercaptoethanol. The mixture was incubated at $70^{\circ} \mathrm{C}$ with intermittent shaking for $10 \mathrm{~min}$, placed on ice for $5 \mathrm{~min}$, and then centrifuged at $13,000 \times g$ for $10 \mathrm{~min}$. Three hundred microliters of the supernatant fluid was then transferred to a new tube to which was added $150 \mu \mathrm{l}$ of ethanol, $300 \mu \mathrm{l}$ of $6 \mathrm{M}$ sodium iodide, and $25 \mu \mathrm{l}$ of resuspended silica, incubated at room temp for 10 min with intermittent shaking, and then centrifuged at $6,000 \times g$ for $1 \mathrm{~min}$. The pellet was resuspended in $500 \mu \mathrm{l}$ of wash buffer $(10 \mathrm{mM}$ Tris-HCl, $\mathrm{pH} 7.5,0.5 \mathrm{mM}$ EDTA, $50.0 \mathrm{mM} \mathrm{NaCl}, 50 \%$ ethanol) and centrifuged at $6,000 \times g$ for $1 \mathrm{~min}$. The wash step was repeated once, and the pellet was allowed to dry for several minutes at room temperature before resuspending in $150 \mu \mathrm{l}$ of sterile distilled water. The mix- 
ture was incubated at $70^{\circ} \mathrm{C}$ for 4 min, centrifuged at $13,000 \times g$ for $3 \mathrm{~min}$, and the supernatant fluid transferred to a new tube and stored at $-20^{\circ} \mathrm{C}$.

Detection of SMoV using RT-PCR. For reverse transcription, $5 \mu \mathrm{l}$ of total nucleic acid extract in $6.5 \mu \mathrm{l}$ of sterile distilled water and $0.5 \mu$ of sense primer $(10 \mu \mathrm{M})$ were added; $4 \mu \mathrm{l}$ of first strand buffer (5x) (Invitrogen, $\mathrm{GmbH}$, Karlsruhe, Germany), $2 \mu$ of DTT $(0.1 \mathrm{M})$, and $1 \mu \mathrm{l}$ dNTP's $(10 \mathrm{mM})$ were added and incubated at $37^{\circ} \mathrm{C}$ for $10 \mathrm{~min}$; $1 \mu \mathrm{l}$ of MMLV or Superscript II (200 U/ $\mu \mathrm{l})$ (Invitrogen) was added and incubated at $42^{\circ} \mathrm{C}$ for $50 \mathrm{~min}$. The enzyme was inactivated by incubating at $70^{\circ} \mathrm{C}$ for 10 min. PCR was done using Titanium Taq DNA Polymerase (Clontech, Palo Alto, CA) according to the manufacturer's instructions in a Robocycler (Stratagene, Heidelberg, Germany). Sense and antisense primers were, respectively, Smdetncr4a 5' TAAGCGACCACGACTGTGACAAAG $3^{\prime}$ and Sm2ncr1b 5' ATTCGGTTCACGTCCTAGTCTCAC $3^{\prime}$. For all primer pairs, cycling conditions consisted of an initial denaturation step at $94^{\circ} \mathrm{C}$ for $2 \mathrm{~min}$, followed by 35 cycles at $94^{\circ} \mathrm{C}$ for $1 \mathrm{~min}$, $50^{\circ} \mathrm{C}$ for $1 \mathrm{~min}, 72^{\circ} \mathrm{C}$ for $1 \mathrm{~min}$, and a final elongation step at $72^{\circ} \mathrm{C}$ for $5 \mathrm{~min}$. PCR products were separated by electrophoresis in $1 \%$ agarose gels and visualized under UV light after staining with ethidium bromide.

RT-PCR using CPL, RdRp, and degenerate primers. Except for minor modifications, RT-PCR was carried out as above with the following primers. For partial amplification of the CPL region, sense and antisense primers were, respectively, Smcpla 5' GGACCTACGGATCTTGGAAGT $3^{\prime}$ and Smcplb 5' ACCCGCACAACTTGTCGGAGG 3'. For partial amplification of the RdRp region, sense and antisense primers were, re- spectively, Smpolla 5' GCTTGTGCCAAAGATGAGAAA $3^{\prime}$ and Smpollb 5' AGAAACAACGTTGTCGTCTCC 3'. For both the CPL and RdRp primers, lower annealing temperatures, minimum $44^{\circ} \mathrm{C}$, were employed for some samples. Takara La Taq (Takara Shuzo Co., Shiga, Japan) was used with the reaction mixture recommended by the manufacturer. Degenerate primers for CPL were $5^{\prime}$ GRATGACYACYAARGGTTC $3^{\prime}$ and $5^{\prime}$ AARAYNACRAACATCAT $3^{\prime}$, based on the most conserved regions amplified by Smpolla and Smpollb in 11 isolates. Amplification conditions were the same as described above except that the annealing temperature was $42^{\circ} \mathrm{C}$. PCR products were separated by electrophoresis in $1 \%$ agarose gels and visualized under UV light after staining with ethidium bromide.

Cloning, sequencing, and sequence analysis. PCR fragments were excised from the gel by Geneclean (Bio 101, Carlsbad, CA) and ligated into pBluescript KS with a T-overhang (2) at the EcoRV site. Competent Escherichia coli DH5 $\alpha$ cells were then transformed (22) and plated on LB agar supplemented with ampicillin at $100 \mu \mathrm{g} / \mathrm{ml}$ and X-gal at $100 \mathrm{ng} / \mathrm{ml}$. White colonies were then grown in a selective medium, and plasmids were purified using the Concert rapid miniprep system (Invitrogen). Two independent clones from each of the sequences presented here were sequenced on both strands. To check for errors introduced by RT-PCR, a transcript generated from a 300-bp insert in pBluescript KS was reverse transcribed as described above and then amplified in 10 independent PCRs using Titanium Taq DNA polymerase. The generated fragments were then cloned, sequenced, and analyzed. All clones were sequenced with an ABI Prism Sequence Detection System (Applied Biosystems, Foster City, CA) and analyzed with the HUSAR computer program (German Cancer Research Center, Heidelberg, Germany). Multiple alignments were then done with the CLUSTAL X program (25) after bootstrapping in 1,000 replicates. Phylogenies were viewed by the NJplot program (16). Percent nucleotide and amino acid similarities between sequences were calculated using the HUSAR program.

\section{RESULTS}

Detection of SMoV isolates by RTPCR. All 16 isolates (Table 1), tested by RT-PCR with primers Smdetncr4a and

Table 1. Isolates testing positive for Strawberry mottle virus (SMoV) using primers Smdetncr4a and Smdetncr1b

\begin{tabular}{|c|c|c|c|c|c|c|}
\hline Isolate & Country ${ }^{\mathbf{a}}$ & Host $^{\text {b }}$ & Symptoms $^{\mathrm{c}}$ & Year $^{\text {d }}$ & $\mathrm{CPL}^{\mathrm{e}}$ & POL ${ }^{e}$ \\
\hline 197/3A & $\mathrm{CZ}$ & F. ananassa & - & 1989 & AJ496149 & AJ496161 \\
\hline 197/3B & $\mathrm{CZ}$ & $\mathrm{UC} 4$ & + & 1989 & AJ496150 & AJ496162 \\
\hline $1509 / 4$ & PL & UC5 & ++ & 1999 & AJ496147 & AJ496159 \\
\hline 1248 & PL & $\mathrm{UC} 10$ & ++ & 1999 & AJ496142 & AJ496157 \\
\hline 167 & PL & UC10 & +++ & 1999 & AJ496148 & AJ496160 \\
\hline HD & $\mathrm{DE}$ & UC4 & +++ & 1975 & AJ496153 & NT \\
\hline ST & $\mathrm{DE}$ & $\mathrm{UC} 4$ & + & 1975 & AJ496154 & NT \\
\hline $1134^{\mathrm{e}}$ & NL & UC5 & ++ & 1987 & AJ311876 & AJ311875 \\
\hline 1141 & NL & UC5 & +++ & 1987 & AJ496140 & NT \\
\hline 1166 & NL & UC5 & + & 1987 & AJ496141 & AJ496156 \\
\hline 1265 & NL & UC5 & + & 1987 & AJ496143 & NT \\
\hline 1266 & NL & UC5 & + & 1987 & AJ496144 & NT \\
\hline 1278 & NL & UC5 & ++ & 1987 & AJ496145 & AJ496158 \\
\hline 1280 & NL & UC5 & + & 1987 & AJ496146 & NT \\
\hline $9032.001 \mathrm{M} 7$ & US & F. vesca & ++ & $1960 \mathrm{~s}$ & AJ496152 & NT \\
\hline $3 \mathrm{CH}$ & $\mathrm{CH}$ & F. chiloensis & - & 2001 & AJ496151 & AJ496163 \\
\hline
\end{tabular}

${ }^{a}$ Country of origin: CZ, Czech Republic; PL, Poland; DE, Germany; NL, The Netherlands; US, United States of America; CH, Chile.

b Host description: species or indicator plant (UC4, Fragaria vesca and $F$. virginiana hybrid; UC5, F. vesca, F. chiloensis, and $F$. virginiana hybrid; UC10, F. virginiana).

c Degree of symptoms: -, symptomless; +, slight mottle; ++, severe mottle; +++, severe mottle with leaf deformation.

d Year collected.

e Accession numbers for each sequence of each isolate are included under respective headings CPL and POL. Accession numbers for isolate 1134 are for the complete sequence of RNA1 and 2 (26). NT, not tested. 
Sm2ncr1b, were positive for the SMoVspecific product (Fig. 1). The PCR fragment was $460 \mathrm{bp}$ long. The isolates had all previously been identified as SMoV by transmission to indicator plants (results not shown). Intensity of the fragments varied, although with even the faintest there could be no ambiguity as to the result. The less intense bands of the Dutch isolates can be most likely explained on the grounds that the materials were frozen before extraction. The PCR products of 11 out of the 16 isolates were sequenced. An alignment between all isolates and RNA1 and RNA2 of isolate 1134 was made (Fig 2), the latter two sequences being from previously obtained data (26). Four completely conserved regions of 20 or more bases ( 3 to 27, 56 to 78,120 to 139,154 to 190 ) were identified. There were no gaps in the alignment except at positions 346 to 354 where, for all isolates except 197/3A, a gap of one to five bases was present.
Variation in CPL and RdRp regions. The primers used to partially amplify the CPL and RdRp regions were based on conserved regions within the genome. CPL and RdRp primers were located in RNA2 at 2092 to 2112 and 2553 to 2533, and in RNA1 at 4423 to 4444 and 5010 to 4990 , respectively. For the CPL region, the conserved amino acid motifs LGS and PPT were identified by alignment of SMoV, with the related picorna-like viruses, SDV (Acc. no. D88459), Navel orange infectious mottling virus (NIMV) (Acc. no. $\mathrm{AB} 000282)$, and Citrus mosaic virus (CiMV) (Acc. no. AB032751) (23). These motifs served as the template for the $3^{\prime}$ end of the primers. For the RdRp region, the conserved amino acid motifs KxEK and GDD, designated motifs I and VI by Koonin (7), served similarly as templates for primer design. In alignments with other related viruses, these two motifs were the most conserved. Amplification of both regions proved difficult, more often than not resulting in no product or the amplification of a spurious product, especially at lower annealing temperatures. RdRp primers successfully yielded fragments of the correct size in nine of the isolates, while CPL primers yielded products from 11 isolates: 197/3A, 197/3B, 1509/4, HD, ST, 1134, 1141, 1265, 1280, 9032.001M7, 3CH. The use of Takara La Taq DNA polymerase improved amplification of the desired products at lower annealing temperatures for certain isolates. Degenerate primers designed in the same region as the CPL and RdRp primers were no better at amplifying the expected fragments (results not shown). Degenerate primers were also designed on the most conserved regions of those extant sequences generated by the $\mathrm{CPL}$ and RdRp primers. For the CPL region, all remaining isolates were successfully amplified and cloned. For the RdRp region, amplification using these

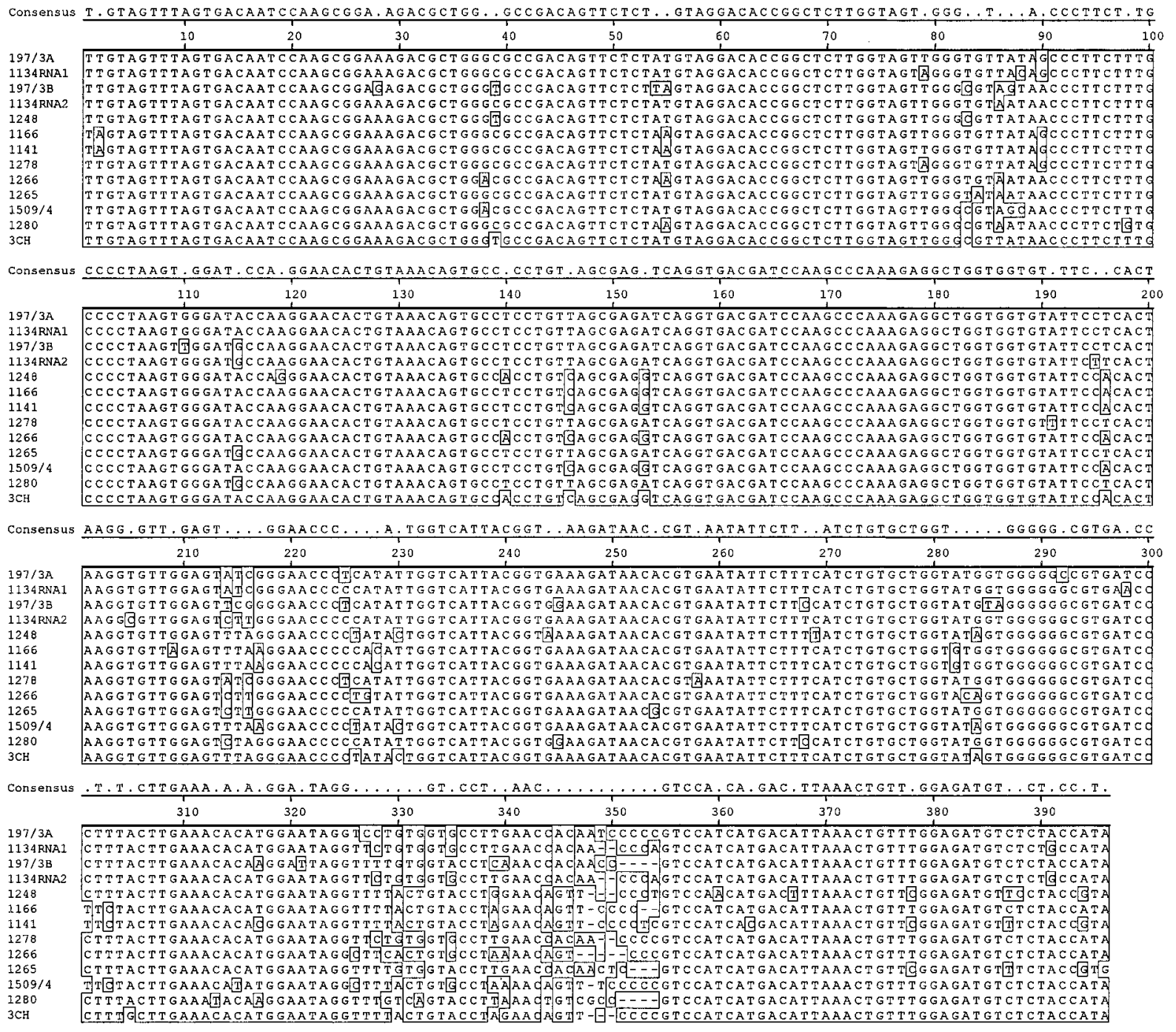

Fig 2. Alignment of a 396-nt stretch within the 3' noncoding region of 11 isolates of Strawberry mottle virus (SMoV) and RNA1 and 2 of isolate 1134 . The consensus, which indicates bases common to all isolates, is shown at the top. Those bases, for each position, that are in a minority are boxed. Position of sequence within genome of isolate 1134 is for RNA1 6209-6602, and for RNA2 4792-5185. Accession numbers with isolate name in parentheses: AJ496581 (1141), AJ496582 (1166), AJ496583 (1248), AJ496584 (1265), AJ496585 (1266), AJ496586 (1278), AJ496587 (1280), AJ496588 (1509/4), AJ496589 (197/3A), AJ496590 (197/3B), AJ496591 (3CH). 
degenerate primers was unsuccessful, with spurious amplification.

Sequence analysis of the putative CPL region (327 nt; 108 aa) showed nucleotide and amino acid identities ranged from 72.8 to $99.7 \%$ and 92.6 to $100 \%$, respectively (Table 2). The lowest identities were with the two German isolates HD and ST, which formed a separate, although not statistically significant clade. All three Polish isolates $(1509 / 4,1248,167)$ and four Dutch isolates $(1134,1141,1265$, and 1280) formed two separate clades (Fig. 3). Identities of the $546 \mathrm{nt}$ of the putative RdRp gene of nine isolates ranged from 73.4 to $100 \%$, and of the corresponding 182 aa sequence 94 to $100 \%$ (Table 3). All three Polish isolates tested were found to be identical. The phylogenetic relationships between isolates (Fig. 4) were similar to that for the CPL region. Amplification products of the NCR generated by the detection RT-PCR of 11 isolates were cloned and sequenced. Based on the sequence data provided by 10 clones (not shown) generated by RT-PCR from one transcribed clone, the percent RT-PCR error frequency [(number of base misincorporations/ number of bases analyzed) $\times 100$ ] was calculated to be $0.12 \%$. Such an error rate did not affect the relationships determined among isolates.

\section{DISCUSSION}

The RT-PCR method for detection of $\mathrm{SMoV}$ in Fragaria spp. as described here has a clear advantage over the present indexing methods, enabling a faster, more reliable indexing of strawberry material. The choice of which region of the viral genome to use was based on two observations: first, that it had already been shown for the nepovirus Cherry leaf roll virus (CLRV) (1) that there was a relatively high degree of conservation in the $3^{\prime}$ noncoding region $\left(3^{\prime} \mathrm{NCR}\right)$ between isolates, and second, that the degree of homology between the $3^{\prime} \mathrm{NCRs}$ of RNA1 and 2 for SMoV isolate 1134 was also high (95.7\%), in theory providing a higher template molarity than for any other region within the genome. Based on the alignment of RNA1 and 2 of SMoV isolate 1134, various primers were designed and tested, and finally the pair used in this study was selected.

One of the main obstacles to overcome in this work was that of finding a suitable nucleic acid extraction method for Fragaria spp. material, which along with other berry plants is known to be particularly recalcitrant. Secondary metabolites, such as tannins, polyphenols, and polysaccharides, reportedly inhibit $T a q$ polymerase activity (17). Among the methods reported $(10,14,17,23)$, the cheapest, fastest, and most reliable method was the adapted sil-

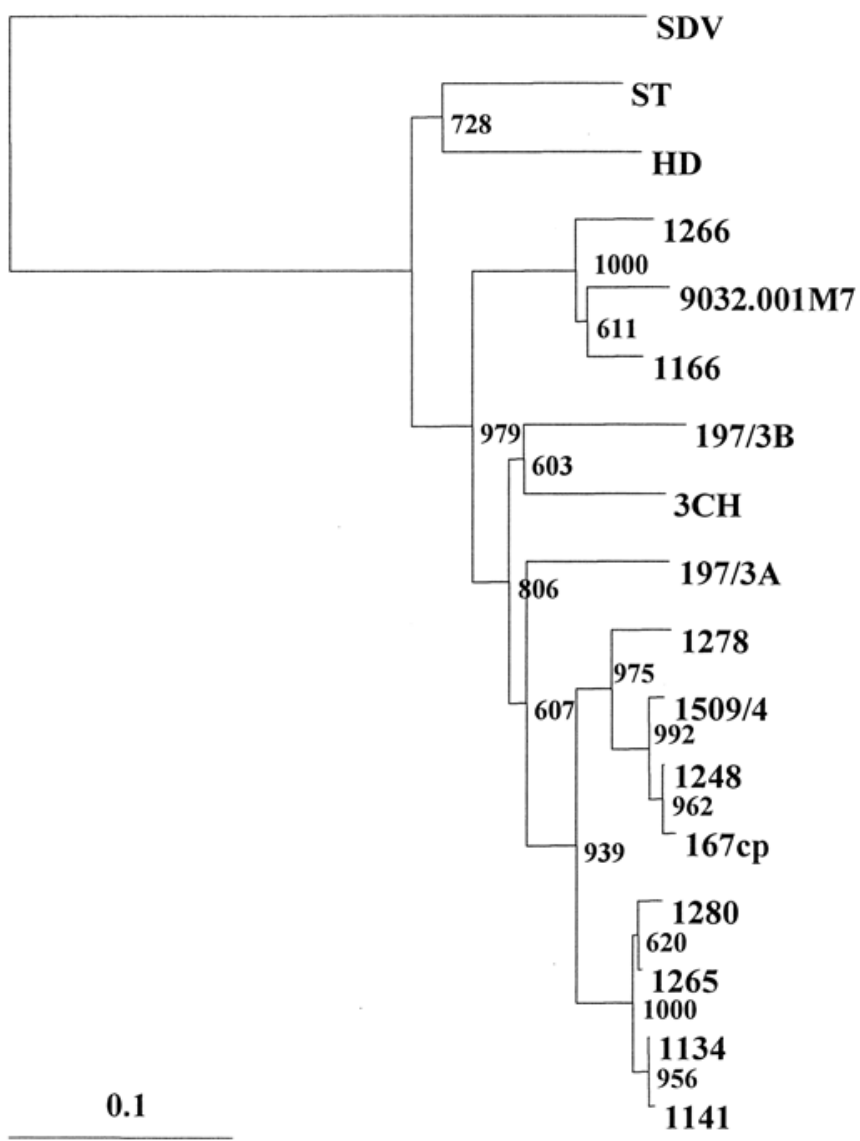

Fig 3. Phylogenetic tree based on the alignment from various isolates of a 546-nt stretch within the putative RNA-dependent RNA polymerase gene of Strawberry mottle virus (SMoV). Description of the isolates is shown in Table 1. Bootstrap values for 1,000 replicates are given at each node. The scale bar represents the number of substitutions for each base. Satsuma dwarf virus (SDV) (Acc. No. AB009958) was used as the outgroup.

Table 2. Percent nucleotide (above diagonal) and amino acid (below diagonal) identities between 16 isolates of Strawberry mottle virus (SMoV) based on a $327 \mathrm{nt} / 108$ aa region of the putative large coat protein gene (CPL)

\begin{tabular}{|c|c|c|c|c|c|c|c|c|c|c|c|c|c|c|c|c|}
\hline & 197/3A & 197/3B & $1509 / 4$ & 1248 & 167 & HD & ST & 1134 & 1141 & 1166 & 1265 & 1266 & 1278 & 1280 & $\begin{array}{c}\text { 9032. } \\
\text { 001M7 }\end{array}$ & 3CH \\
\hline 197/3A & & 83.2 & 87.8 & 86.5 & 85.3 & 79.8 & 77.4 & 86.9 & 86.2 & 83.5 & 87.8 & 83.5 & 86.2 & 87.8 & 80.7 & 85.0 \\
\hline 197/3B & $\overline{97.2}$ & & 83.2 & 83.2 & 82.0 & 72.8 & 77.7 & 85.9 & 85.9 & 82.0 & 85.9 & 80.7 & 82.6 & 85.6 & 79.8 & 86.5 \\
\hline $1509 / 4$ & 97.2 & $\overline{96.3}$ & & 98.5 & 97.2 & 75.8 & 75.8 & 92.4 & 92.0 & 84.1 & 92.7 & 83.8 & 94.8 & 91.7 & 81.0 & 87.2 \\
\hline 1248 & 97.2 & 96.3 & $\overline{100}$ & & 98.8 & 75.5 & 76.1 & 93.0 & 92.7 & 84.4 & 93.3 & 83.2 & 94.2 & 92.4 & 80.7 & 87.8 \\
\hline 167 & 96.3 & 95.4 & 99.1 & 99.1 & & 75.2 & 77.4 & 91.7 & 91.4 & 84.1 & 92.0 & 82.0 & 93.3 & 91.1 & 82.0 & 86.5 \\
\hline HD & 91.7 & 92.6 & 90.7 & 90.7 & 91.7 & & 82.3 & 75.8 & 76.5 & 74.9 & 75.2 & 76.5 & 76.1 & 74.9 & 74.9 & 76.1 \\
\hline ST & 94.4 & 93.5 & 91.7 & 91.7 & 92.6 & 96.3 & 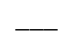 & 78.3 & 78.9 & 78.3 & 78.3 & 77.7 & 75.2 & 78.9 & 78.0 & 74.3 \\
\hline 1134 & 96.3 & 97.2 & 99.1 & 99.1 & 98.1 & 91.7 & 92.6 & - & 99.7 & 83.5 & 99.1 & 82.3 & 92.0 & 97.9 & 80.4 & 86.2 \\
\hline 1141 & 96.3 & 97.2 & 99.1 & 99.1 & 98.1 & 91.7 & 92.6 & $\overline{100}$ & & 84.1 & 98.8 & 82.9 & 91.7 & 97.6 & 81.0 & 85.6 \\
\hline 1166 & 94.4 & 93.5 & 93.5 & 93.5 & 94.4 & 91.7 & 91.7 & 92.6 & 92.6 & - & 83.5 & 92.7 & 83.2 & 82.9 & 93.3 & 81.7 \\
\hline 1265 & 96.3 & 97.2 & 99.1 & 99.1 & 98.1 & 91.7 & 92.6 & 100 & 100 & $\overline{92.6}$ & & 82.3 & 91.7 & 98.8 & 80.4 & 85.9 \\
\hline 1266 & 95.4 & 94.4 & 94.4 & 94.4 & 93.5 & 90.7 & 90.7 & 93.5 & 93.5 & 99.1 & 93.5 & & 82.9 & 82.6 & 92.4 & 81.7 \\
\hline 1278 & 95.4 & 94.4 & 98.1 & 98.1 & 98.1 & 89.8 & 90.7 & 97.2 & 97.2 & 92.6 & 97.2 & 92.6 & & 90.5 & 82.0 & 87.2 \\
\hline 1280 & 96.3 & 97.2 & 99.1 & 99.1 & 98.1 & 91.7 & 92.6 & 100 & 100 & 92.6 & 100 & 93.5 & $\overline{97.2}$ & & 80.4 & 85.3 \\
\hline $\begin{array}{l}9032 . \\
001 \mathrm{M} 7\end{array}$ & 91.7 & 92.6 & 90.7 & 90.7 & 91.7 & 90.7 & 90.7 & 91.7 & 91.7 & 97.2 & 91.7 & 96.3 & 89.8 & $\overline{91.7}$ & $\ldots$ & 78.6 \\
\hline $3 \mathrm{CH}$ & 99.1 & 98.1 & 98.1 & 98.1 & 97.2 & 92.6 & 93.5 & 97.2 & 97.2 & 95.4 & 97.2 & 96.3 & 96.3 & 97.2 & 92.6 & - \\
\hline
\end{tabular}


ica capture method described here. The silica capture method described by Rott and Jelkmann (21), from which the method here was adapted, was not adequate in that subsequent RT-PCRs were not consistent. Inconsistency in PCR detection of viruses in Fragaria spp. has also been reported for SCV (18) and SVBV (13). Nevertheless, by a 1 in 6 dilution of the sample homogenate in SEB prior to nucleic acid extraction, a robust and reliable detection method was provided (M. Klerks, personal communication), as confirmed by the effectiveness of primers Smdetncr4a and Sm2ncr1b. This can be simply explained on the basis that viral RNA is still at a sufficiently high concentration to be detected, and that the inhibitory effects of other compounds present in the extraction are sufficiently reduced so as to become negligible. Other dilutions of the sample homogenate were tested, but the dilution used here appeared optimal for the primers used.

The initial amplification by RT-PCR of the RdRp and CPL regions using primers designed around conserved motifs was successful only for certain isolates. The most likely explanation for this is that nucleotide sequence variation was such that the primers were unable to anneal efficiently. This was further supported by the fact that those isolates that failed to produce a product with the RdRp primers were for German isolates HD and ST, the most divergent genetically, as indicated by the phylogram for the CPL region (Fig. 3). The U.S. isolate may also have evaded PCR amplification for the same reason. The use of degenerate primers based on the most conserved regions in the CPL region enabled the remaining isolates to be amplified and analyzed. The degree of degeneracy in the CPL-specific primers used here was greater than that for a degenerate pair of primers designed for the RdRp region, although curiously the latter pair was not effective at yielding a specific product (results not shown).

Sequence alignment of the amplified products generated using the detection provided information on the level of homology between isolates, and serves as a template for further refinements in future detection methods. The alignment shown in Figure 2 cannot be used in any analyses, as it is unclear, except for isolate 1134, from which RNA species the fragment is derived.

In analyzing the CPL and RdRp partial sequences, it is important not to lose sight of the fact that together they only represent approximately $7 \%$ of the complete genome, although that is not to say that the results are not representative and cannot be extrapolated to provide information on phylogenies. Indeed, although for seven isolates no sequence data were obtained on the $\mathrm{RdRp}$ region, the fact that the phylograms for both regions of the genome somewhat resemble each other provides additional evidence for the above assumption. In terms of the grouping within the phylograms for the CPL and RdRp regions (Figs. 3 and 4), there was a clear indication that the isolates grouped according to their geographical origin. This was certainly true for the Polish isolates, which were identical at a nucleic acid level in the $\mathrm{RdRp}$ region. The Dutch isolates also had a tendency to group together with some divergent isolates for the CPL region. Interestingly, the two New World isolates $(3 \mathrm{CH}$ and $9032.001 \mathrm{M} 7$ ), although probably in no way sympatric, were grouped separately with other European isolates; the Chilean isolate formed a single branch in both phylograms. Given the geographical correlation with phylogenies, the two Czech isolates (197/3A and 197/3B) were especially divergent considering they may have originally come from the same source, although their exact history is uncertain. The resulting divergence in this case may be due to either contamination from a distinct source or adaptation to a different host over prolonged isolation, possibly as a result of either quasi-species-like characteristics, as identified for the nepovirus Grape fanleaf virus (15), or genetic drift. In comparison

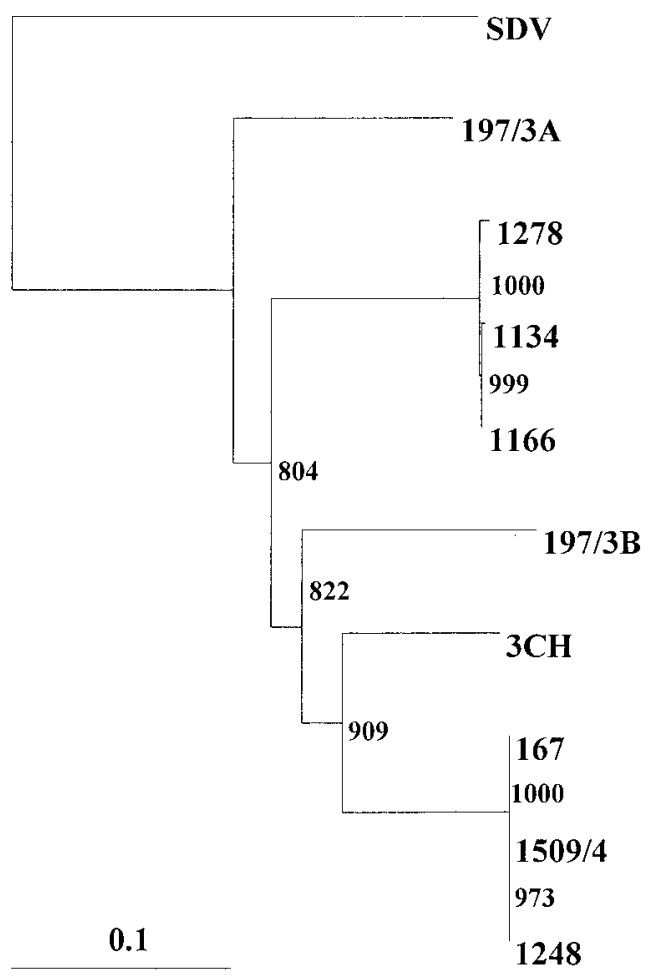

Fig 4. Phylogenetic tree based on the alignment from various isolates of a 327-nt stretch within the putative large coat protein gene of Strawberry mottle virus (SMoV). Description of the isolates is shown in Table 1. Bootstrap values for 1,000 replicates are given at each node. The scale bar represents the number of substitutions for each base. Satsuma dwarf virus (SDV) (Acc. No. AB009959) was used as the outgroup.

Table 3. Percent nucleotide (above diagonal) and amino acid (below diagonal) identities between nine isolates of Strawberry mottle virus (SMoV) based on a $546 \mathrm{nt} / 182$ aa region of the putative RNA-dependent RNA polymerase

\begin{tabular}{|c|c|c|c|c|c|c|c|c|c|}
\hline & 197/3A & 197/3B & $1509 / 4$ & 1248 & 167 & 1134 & 1166 & 1278 & $3 \mathrm{CH}$ \\
\hline 197/3A & & 73.4 & 76.6 & 76.6 & 76.6 & 75.1 & 75.3 & 74.5 & 76.7 \\
\hline $197 / 3 \mathrm{~B}$ & $\overline{94.0}$ & & 77.8 & 77.8 & 77.8 & 76.2 & 76.4 & 76.2 & 79.5 \\
\hline $1509 / 4$ & 94.0 & 95.1 & 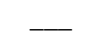 & 100.0 & 100.0 & 77.1 & 77.3 & 76.7 & 84.6 \\
\hline 1248 & 94.0 & 95.1 & $1 \overline{00.0}$ & & 100.0 & 77.1 & 77.3 & 76.7 & 84.6 \\
\hline 167 & 94.0 & 95.1 & 100.0 & $1 \overline{00.0}$ & & 77.1 & 77.3 & 76.7 & 84.6 \\
\hline 1134 & 94.5 & 95.1 & 95.1 & 95.1 & 95.1 & & 99.8 & 99.3 & 78.2 \\
\hline 1166 & 95.1 & 95.6 & 95.6 & 95.6 & 95.6 & $\overline{99.5}$ & 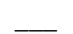 & 99.5 & 78.4 \\
\hline 1278 & 94.0 & 94.5 & 95.1 & 95.1 & 95.1 & 98.4 & $\overline{98.9}$ & & 77.7 \\
\hline $3 \mathrm{CH}$ & 94.0 & 96.2 & 98.9 & 98.9 & 98.9 & 95.1 & 95.6 & $\overline{94.5}$ & 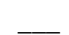 \\
\hline
\end{tabular}


with the SDV group of viruses, in which $\mathrm{SMoV}$ is tentatively classified, the percent amino acid identities found for the complete CPL are lower, ranging from 82 to $98 \%$ (4). It may well be the case that for $\mathrm{SMoV}$, the homology between isolates outside the region sequenced here is significantly lower. A CP amino acid motif of high homology shared with more distantly related viruses, including several picornaviruses and sequiviruses, and found consistently in all $\mathrm{SMoV}$ isolates was GxUxUxxxPxG, where $x$ represents any base and $U$ represents the bulky aliphatic residues (I, L, M, V) (5). Similarly, the RdRp motifs of positive-strand RNA viruses V (SGxxxTxxxNSUU) and IV (DxTxxD) were also present (7).

In summary, this work has developed an RT-PCR detection method for SMoV and provides sequence information that should lead to yet further improvements in detection. It also firmly associates $\mathrm{SMoV}$ with the disease and gives an insight into the degree of variation and the genetic relationships between isolates.

\section{ACKNOWLEDGMENTS}

We are very grateful to Sabine Wetzel for her technical support. Many thanks also to Michel Klerks (IPO, Wageningen, Holland) for his sound advice on purification techniques and to Robert Martin (USDA, Corvallis, OR) for critically reviewing this article and donating the American isolate. For providing the other isolates, we are indebted to Michel Klerks and Cor Schoen (IPO), Renata Karesova (RBIP, Horice, Czech Republic), Mirka Cieslinska (ISK, Skierniewice, Poland), and Ruperto Hepp (Universidad de Concepcion, Chillan, Chile). This work was funded by European Community Project no. QLRT-PL99-1553.

\section{LITERATURE CITED}

1. Borja, M., Sanchez, F., Rowhani, A., Bruening, G., and Ponz, F. 1995. Long, nearly identical untranslated sequences at the $3^{\prime}$ terminal regions of the genomic RNA's of Cherry leafroll virus (Walnut strain). Virus Genes 10:245-252.

2. Hadjeb, N., and Berkowitz, G. A. 1996. Preparation of T-overhang vectors with high
PCR product cloning efficiency. Biotechniques 20:20-22.

3. Horn, N. L., and Carver, R. G. 1962. Effect of three viruses on plant production and yields of strawberries. Plant Dis. Rep. 46:762-765.

4. Iwanami, T., Kondo, Y., Kobayashi, M., Han, S. S., and Karasev, A. V. 2001. Sequence diversity and interrelationships among isolates of satsuma dwarf virus. Arch. Virol. 146:807813.

5. Karasev, A. V., Han, S. S., and Iwanami, T. 2001. Satsuma dwarf and related viruses belong to a new lineage of plant picorna-like viruses. Virus Genes 23:45-52.

6. Kitajima, E. W., Betti, J. A., and Costa, A. S. 1971. Isometric, viruslike particles in leaf tissues of Fragaria vesca L. infected with strawberry mottle virus. Ciencia Cultura 23:649-655.

7. Koonin, E. V. 1991. The phylogeny of RNAdependent RNA polymerases of positivestrand RNA viruses. J. Gen. Virol. 72:21972206.

8. Leone, G., Lindner, J. L., and Schoen, C. D. 1992. Attempts to purify strawberry viruses by non-conventional separation methods. Acta Hortic. 308:121-129.

9. Leone, G., Lindner, J. L., and Schoen, C. D. 1995. Unstable infectivity and abundant viral RNAs associated with strawberry mottle virus. Acta Hortic. 385:76-85.

10. Manning, K. 1991. Isolation of nucleic acids from plants by differential solvent precipitation. Anal. Biochem. 195:45-50.

11. Mayo, M. A., and Robinson, D. J. 1996. Nepoviruses: Molecular biology and Replication. Pages 139-185 in: The Plant Viruses, Vol 5. B. D. Harrison and A. F. Murant, eds. Plenum Press, New York.

12. Mellor, F. C., and Krczal, H. 1987. Strawberry mottle. Pages 10-16 in: Virus Diseases of Small Fruits. R. H. Converse, ed. U.S. Dep. Agric. Agric. Handb. 631.

13. Mraz, I., Petrzik, K., Chvalova, D., Sip, M., and Franova, J. 1999. Experiences with testing of Strawberry veinbanding virus in strawberries by PCR and dot blot hybridisation. J. Plant Dis. Prot. 106:231-236.

14. Nakahara, K., Hataya, T., and Uyeda, I. 1999. A simple, rapid method of nucleic acid extraction without tissue homogenization for detecting viroids by hybridization and RT-PCR. J. Virol. Methods 77:47-58.

15. Naraghi-Arani, P., Daubert, S., and Rowhani, A. 2001. Quasispecies nature of the genome of Grapevine fanleaf virus. J. Gen. Virol.
82:1791-1795.

16. Perrière, G., and Gouy, M. 1996. WWWQuery: An on-line retrieval system for biological sequence banks. Biochemie 78:364369.

17. Porebski, S., Bailey, L. G., and Baum, B. R 1997. Modification of a CTAB DNA extraction protocol for plants containing high polysaccharide and polyphenol components. Plant Mol. Biol. Rep. 15:8-15.

18. Posthuma, K. I., Hong, Y. G., and Adams, A. N. 2000. Molecular detection of Strawberry crinkle virus. Acta Hortic. 551:75-79.

19. Prentice, I. W. 1948. Resolution of strawberry virus complexes II. Virus 2 (mild yellow-edge virus). Ann. Appl. Biol. 35:279-289.

20. Prentice, I. W., and Harris, R. V. 1946. Resolution of strawberry virus complexes by means of the aphid vector Capitophorus fragariae Theb. Ann. Appl. Biol. 33:50-53.

21. Rott, M. E., and Jelkmann, W. 2001. Characterization and detection of several filamentous viruses of cherry: Adaptation of an alternative cloning method (DOP-PCR), and modification of an RNA extraction protocol. Eur. J. Plant Pathol. 107:411-420.

22. Sambrook, J., Fritsch, E. F., and Maniatis, T. 1989. Molecular Cloning - A Laboratory Manual. Cold Spring Harbor Laboratory, Cold Spring Harbor, NY.

23. Singh, R. P. 1998. Reverse-transcription polymerase chain reaction for the detection of viruses from plants and aphids. J. Virol. Methods 74:125-138.

24. Thomas, H. E. 1949. The strawberry virus complex. (Abstr.) Phytopathology 39:863.

25. Thompson, J. D., Gibson, T. J., Plewniak, F., Jeanmougin, F., and Higgins, D. G. 1997. The ClustalX windows interface: Flexible strategies for multiple sequence alignment aided by quality analysis tools. Nucleic Acids Res. 25:4876-4882.

26. Thompson, J. R., Leone, G., Lindner, J. L., Jelkmann, W., and Schoen, C. D. 2002. Characterization and complete nucleotide sequence of Strawberry mottle virus: A tentative member of a new family of bipartite plant picorna-like viruses. J. Gen. Virol. 83:229-239.

27. van den Heuvel, J. F. J. M., and Peters, D. 1989. Improved detection of potato leafroll virus in plant material and in aphids. Phytopathology 79:963-967.

28. Yoshikawa, N., and Converse, R. H. 1991 Purification and some properties of strawberry mottle virus. Ann. Appl. Biol. 118:565-576. 
ERRATUM / Volume 87, Number 4, 2003

In the article "The Detection and Variation of Strawberry mottle virus" by J. R. Thompson and W. Jelkmann, pages 385-390, the captions for Figures 3 and 4 were reversed. They should appear as follows.

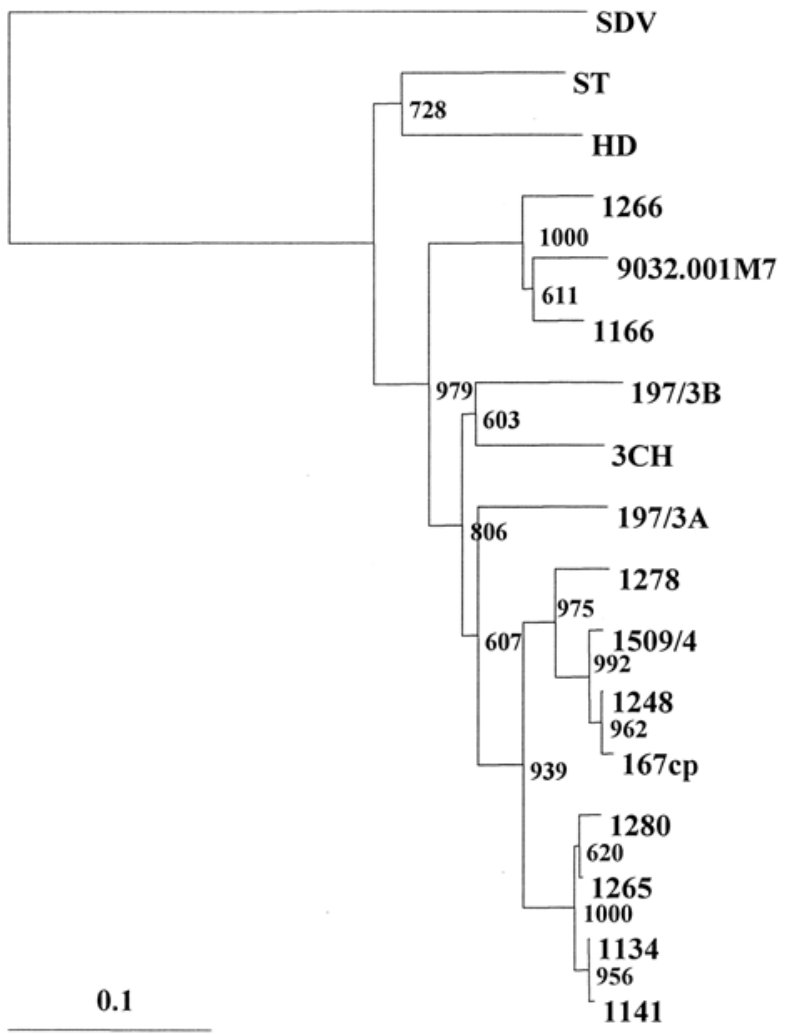

Fig 3. Phylogenetic tree based on the alignment from various isolates of a 327-nt stretch within the putative large coat protein gene of Strawberry mottle virus $(\mathrm{SMoV})$. Description of the isolates is shown in Table 1. Bootstrap values for 1,000 replicates are given at each node. The scale bar represents the number of substitutions for each base. Satsuma dwarf virus (SDV) (Acc. No. AB009959) was used as the outgroup.

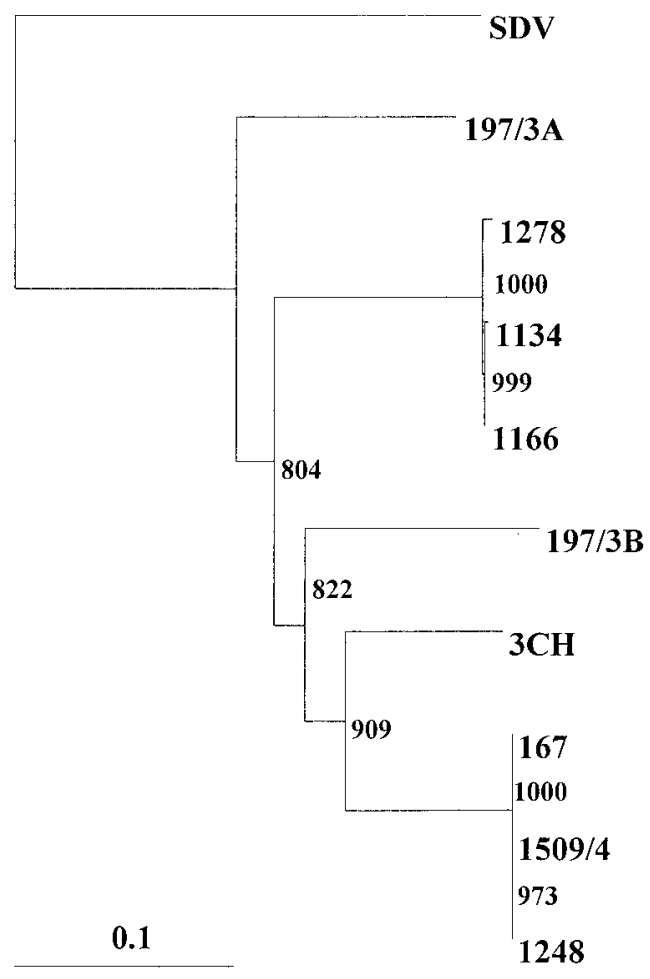

Fig 4. Phylogenetic tree based on the alignment from various isolates of a 546-nt stretch within the putative RNA-dependent RNA polymerase gene of Strawberry mottle virus $(\mathrm{SMoV})$. Description of the isolates is shown in Table 1. Bootstrap values for 1,000 replicates are given at each node. The scale bar represents the number of substitutions for each base. Satsuma dwarf virus (SDV) (Acc. No. AB009958) was used as the outgroup. 